\title{
Evaluating Treatments and Spray Application for the Protection of Grapevine Pruning Wounds from Infection by Eutypa lata
}

Mark R. Sosnowski, Adrian P. Loschiavo, and Trevor J. Wicks, South Australian Research and Development Institute, Urrbrae, SA 5064, Australia; and Eileen S. Scott, School of Agriculture, Food and Wine, The University of Adelaide, Waite Campus, Glen Osmond, SA 5064, Australia

\begin{abstract}
Sosnowski, M. R., Loschiavo, A. P., Wicks, T. J., and Scott, E. S. 2013. Evaluating treatments and spray application for the protection of grapevine pruning wounds from infection by Eutypa lata. Plant Dis. 97:1599-1604.

Eutypa dieback threatens the sustainability of vineyards worldwide and limited treatments are available for control of the disease in grapevine. Following the loss of the effective benzimidazole fungicides, benomyl and carbendazim, there is a need to identify alternatives for the protection of pruning wounds against infection by ascospores of Eutypa lata. In this study, 24 fungicide and natural treatments were evaluated in the laboratory and field. Tebuconazole and carbendazim were the most effective fungicides for reducing colonization of pruning wounds inoc-

ulated with E. lata. Pyrimethanil and fluazinam also provided some control but were less effective than tebuconazole at the rates tested. Other treatments, such as cyprodinil + fludioxionil, pyraclostrobin, a garlic extract, and lactoferrin, reduced colonization of wounds by $E$. lata but require further evaluation at higher concentrations. Carbendazim applied to pruning wounds using tractor-driven sprayers reduced the incidence of pruning wound infection by $E$. lata to levels similar to that achieved by application with a paint brush.
\end{abstract}

Eutypa dieback is a trunk disease of grapevine (Vitis spp.) that occurs worldwide (10) and is caused by the fungus Eutypa lata (Pers.) Tul. \& C. Tul, which belongs to the family Diatrypaceae. The disease was reported to cause yield loss of $1,500 \mathrm{~kg} / \mathrm{ha}$ in Australian Shiraz vineyards when $47 \%$ of vines were affected (40) and contributes to economic losses of US\$260 million per annum in California (36).

Ascospores that develop in pseudothecia on dead wood infected with $E$. lata are released during rainfall $(8,23,32)$, which often coincides with winter pruning. Ascospores rain-splashed or carried by wind land on wounds and germinate in xylem vessels $(23,32)$. Mycelium colonizes the wood, causing internal, necrotic, wedgeshaped lesions in the cross-section of cordons and trunks, and external cankers around sites of infection, eventually leading to die-back and death of vines $(9,10,24)$. Foliar symptoms include stunted shoots with chlorotic leaves, often cupped and with necrotic margins, and are caused by toxic metabolites produced by the fungus in the wood $(22,26,27,38)$.

Management of Eutypa dieback using cultural practices such as sanitation, timing pruning to avoid rainfall, and delaying pruning until late winter or early spring may help to reduce disease (29). However, these measures are unlikely to prevent infection completely and, with expansion of grapevine plantings in many regions of the world, delaying pruning may be impractical. Double pruning, which involves mechanical pruning in midwinter followed by hand pruning late in the winter or spring, may reduce the incidence of infection (39). Ascospores may spread as far as $50 \mathrm{~km}$ from their source $(23,32)$ and, given the broad host range of E. lata (10), inoculum may be difficult to avoid.

A number of wound treatments have been evaluated in management strategies to prevent infection of grapevines by $E$. lata $(7,16,18,21,25,28,30,34,35,37)$. The most effective of these were the benzimidazole fungicides benomyl and carbendazim; however,

Corresponding author: M. R. Sosnowski,

E-mail: mark.sosnowski@sa.gov.au

Accepted for publication 20 June 2013.

http://dx.doi.org/10.1094/PDIS-02-13-0201-RE

(C) 2013 The American Phytopathological Society benomyl was removed from the market in 2001 (3) and the use of carbendazim on grapevines was prohibited in Australia in 2010 due to public exposure risks (4). Biological alternatives may offer longterm protection but microorganisms require time to colonize the wound, which leaves a window of susceptibility to infection by $E$. lata (13). As a result, new treatments need to be developed for the control of infection by E. lata.

A spraying secateur (pruning shears with pneumatic-powered spray nozzle attached) was developed in the early 1980s to apply benomyl to apricot and grapevine wounds at the time of pruning (12) but factors such as occupational health and safety regulations have prevented widespread adoption. Carter and Price (14) applied benomyl to apricot pruning wounds using a turbomist sprayer, only slightly reducing the incidence of infection following inoculation with E. lata. Ramsdell (33) subsequently reported reduced symptoms of Eutypa dieback in vines treated with benomyl using an airblast sprayer following pruning over a 5-year period. Using a recycle spray system with a different treatment mixture of flusilazole and carbendazim, Lecomte et al. (21) reported reduced infection of pruning wounds by E. lata. More recently, Herche and Gubler (19) reduced infection by $E$. lata by applying myclobutanil to pruning wounds using a tractor-driven sprayer. There has been little adoption by industry of spray application for pruning wound protection, particularly in Australia, perhaps due to the limited efficacy data presented in the above reports or the use of spray equipment different from that in operation in commercial vineyards. Therefore, there is a need to assess the efficacy of applying wound protectants using spray machinery commonly used in vineyards.

The objective of this study was to optimize management of Eutypa dieback in grapevines by (i) identifying fungicides, physical barriers, and other alternative treatments, including natural products, that can prevent infection of grapevine pruning wounds by $E$. lata; and (ii) evaluating the efficacy of applying fungicide to pruning wounds using tractor-driven spray machines.

\section{Materials and Methods}

In vitro evaluation. Two experiments were established in 2007 to evaluate the effect of 13 fungicides and five alternative treatments (Tables 1 and 2) on ascospore germination and mycelial growth of E. lata. Aliquots of commercially formulated fungicides were added to potato dextrose agar (PDA; Difco; Becton, Dickinson and Company) at 1 and 10 parts per million (ppm) of 
active ingredient (a.i.) and $60^{\circ} \mathrm{C}$, prior to pouring into plates $(85$ $\mathrm{mm}$ in diameter, $16 \mathrm{ml} / \mathrm{plate})$. The alternative treatments were likewise added to PDA at 1 and $10 \%$.

The effect of the 18 treatments on ascospore germination was assessed in vitro. Ascospores were prepared using methods described by Sosnowski et al. (37). Stromata on naturally infected, dead grapevine wood were identified as E. lata based on the presence of allantoid ascospores 6.2 to 11 by 1.5 to $2 \mathrm{~mm}$ in size, eight per ascus (10). Briefly, ascospores were obtained from perithecia following soaking of wood segments in distilled water for an hour. The wood segments were then suspended over clean plastic con- tainers overnight, and, the following morning, containers were washed with sterile distilled water (SDW) to suspend ejected ascospores and the suspension was adjusted to $4 \times 10^{3}$ spores $/ \mathrm{ml}$. Five $100-\mu \mathrm{l}$ aliquots were spotted on each of 12 replicate fungicideamended PDA plates per treatment, plus controls of nonamended PDA, and plates were arranged in a randomized block design. Plates were incubated under continuous fluorescent light (Phillips TLD 36W/865 cool daylight; Philips Electronics N.V.) at $23^{\circ} \mathrm{C}$ for $48 \mathrm{~h}$. Up to 100 spores were assessed for germination per replicate, indicated by the presence of a germ tube, and the percentage of germination was calculated.

Table 1. Treatments, active ingredients, and manufacturers of products evaluated to control Eutypa lata in vitro and in the field

\begin{tabular}{|c|c|c|c|}
\hline Treatment & Active ingredient & $\begin{array}{c}\text { Application } \\
\text { rate }(\text { a.i./liter) }\end{array}$ & Manufacturer \\
\hline Acrobat ${ }^{y}$ & Dimethomorph $(500 \mathrm{~g} /$ liter $)$ & $0.18 \mathrm{~g}$ & Nufarm Australia Ltd. \\
\hline Bavistin $^{\mathrm{y}, \mathrm{z}}$ & Carbendazim ( $500 \mathrm{~g} /$ liter) & $0.5 \mathrm{~g}$ & Crop Care Australasia Pty Ltd. \\
\hline Cabrio $^{z}$ & Pyraclostrobin (250 g/liter) & $0.1 \mathrm{~g}$ & Nufarm Australia Ltd. \\
\hline $\operatorname{Domark}^{\mathrm{y}, \mathrm{z}}$ & Tetraconazole (40 g/liter) & $0.012 \mathrm{~g}$ & Sipcam Pacific Australia Pty Ltd. \\
\hline EcoCarb ${ }^{y}$ & Potassium bicarbonate $(940 \mathrm{~g} / \mathrm{kg})$ & $3.76 \mathrm{~g}$ & Organic Crop Protectants Pty Ltd. \\
\hline Folicur ${ }^{\mathrm{y}, \mathrm{z}}$ & Tebuconazole (430 g/liter) & $0.129 \mathrm{~g}$ & Bayer Crop Science Pty Ltd. \\
\hline Foli-R-Fos ${ }^{y}$ & Phosphonic acid (200 g/liter) & $\mathrm{n} / \mathrm{a}$ & U.I.M. Agrochemicals Australia Pty Ltd. \\
\hline Garlic $^{\mathrm{y}, \mathrm{z}}$ & Allium sativum extract & $\mathrm{n} / \mathrm{a}$ & $\mathrm{n} / \mathrm{a}$ \\
\hline Gelseal $^{z}$ & Gel + tebuconazole (10 g/liter) & $\mathrm{n} / \mathrm{a}$ & Omnia Primaxa Ltd. \\
\hline Greenseal $^{\mathrm{z}}$ & Paint + tebuconazole $(10 \mathrm{~g} /$ liter $)$ & $\mathrm{n} / \mathrm{a}$ & Omnia Primaxa Ltd. \\
\hline Honey & $\mathrm{n} / \mathrm{a}$ & $\mathrm{n} / \mathrm{a}$ & Capilano Honey Ltd. \\
\hline Lactoferrin $^{\mathrm{y}, \mathrm{z}}$ & Lactoferrin $(99.9 \%)$ & $\mathrm{n} / \mathrm{a}$ & MG Nutritionals \\
\hline Legend ${ }^{y}$ & Quinoxyfen (250 g/liter) & $0.05 \mathrm{~g}$ & Dow Agrosciences Australia Ltd. \\
\hline Liquicop ${ }^{y}$ & Copper ammonium acetate ( $80 \mathrm{~g} / \mathrm{liter})$ & $0.4 \mathrm{~g}$ & Ekko \\
\hline Mycloss Xtra $^{z}$ & Myclobutanil (200 g/liter) & $0.032 \mathrm{~g}$ & Dow Agrosciences Australia Ltd. \\
\hline Prosper $^{\mathrm{y}}$ & Spiroxamine $(500 \mathrm{~g} /$ liter $)$ & $0.3 \mathrm{~g}$ & Bayer Crop Science Pty Ltd. \\
\hline Proxitane sanitizer ${ }^{\mathrm{y}}$ & Hydrogen peroxide $(250 \mathrm{~g} / \mathrm{liter})$ & $\mathrm{n} / \mathrm{a}$ & Solvay Interox Pty Ltd. \\
\hline Rubigan $^{\mathrm{y}, \mathrm{z}}$ & Fenarimol (120 g/liter) & $0.024 \mathrm{~g}$ & Du Pont Australia Ltd. \\
\hline Sard laundry powdery & $\mathrm{n} / \mathrm{a}$ & $\mathrm{n} / \mathrm{a}$ & Colgate-Palmolive Company \\
\hline Scala $^{y}$ & Pyrimethanil (400 g/kg) & $0.8 \mathrm{~g}$ & Bayer Crop Science Pty Ltd. \\
\hline Shirlan $^{2}$ & Fluazinam $(500 \mathrm{~g} /$ liter $)$ & $0.5 \mathrm{~g}$ & CropCare Australasia Pty Ltd. \\
\hline Switch ${ }^{\mathrm{y}, \mathrm{z}}$ & Cyprodinil $(375 \mathrm{~g} / \mathrm{kg})+$ fludioxionil $(250 \mathrm{~g} / \mathrm{kg})$ & $0.3+0.2 \mathrm{~g}$ & Syngenta Australia Pty Ltd. \\
\hline Systhane ${ }^{y}$ & Myclobutanil (200 g/liter) & $0.032 \mathrm{~g}$ & Dow Agrosciences Australia Ltd. \\
\hline Tea Tree Oil ${ }^{y}$ & Melaleuca alternifolia oil $(15 \% \mathrm{w} / \mathrm{w})$ & $\mathrm{n} / \mathrm{a}$ & Herron Pharmaceuticals Pty Ltd. \\
\hline
\end{tabular}

${ }^{\mathrm{x}}$ Application rate recommended for grapevines in Australia; $\mathrm{n} / \mathrm{a}=$ not applicable.

y Treatments assessed in vitro.

${ }^{\mathrm{z}}$ Treatments assessed in the field.

Table 2. Efficacy of treatments in vitro at concentrations of 1 and $10 \mathrm{ppm}$ a.i. or \% for inhibition of ascospore germination and colony growth of Eutypa lata

\begin{tabular}{|c|c|c|c|c|c|c|c|c|c|c|c|c|}
\hline \multirow[b]{3}{*}{ Treatment } & \multicolumn{12}{|c|}{ Concentration } \\
\hline & \multicolumn{2}{|c|}{ Germination (\%) } & \multicolumn{2}{|c|}{$\begin{array}{l}\text { Colony diameter } \\
(\mathbf{m m})\end{array}$} & \multicolumn{2}{|c|}{$\begin{array}{l}\text { Inhibition of } \\
\text { growth }(\%)^{\mathrm{z}}\end{array}$} & \multicolumn{2}{|c|}{ Germination (\%) } & \multicolumn{2}{|c|}{$\begin{array}{c}\text { Colony diameter } \\
(\mathbf{m m})\end{array}$} & \multicolumn{2}{|c|}{$\begin{array}{l}\text { Inhibition of } \\
\text { growth }(\%)^{z}\end{array}$} \\
\hline & 1 ppm & 10 ppm & 1 ppm & 10 ppm & 1 ppm & 10 ppm & $1 \%$ & $10 \%$ & $1 \%$ & $10 \%$ & $1 \%$ & $10 \%$ \\
\hline Control & $99 \mathrm{a}$ & $99 \mathrm{a}$ & $56 \mathrm{~cd}$ & $56 \mathrm{e}$ & $\ldots$ & $\ldots$ & $\ldots$ & $\ldots$ & $\ldots$ & $\ldots$ & $\ldots$ & $\ldots$ \\
\hline Tebuconazole & $7 \mathrm{~d}$ & $6 \mathrm{e}$ & $12 \mathrm{j}$ & $0 \mathrm{i}$ & 78 & 100 & $\ldots$ & $\ldots$ & $\ldots$ & $\ldots$ & $\ldots$ & $\ldots$ \\
\hline Fenarimol & $28 \mathrm{c}$ & $7 \mathrm{e}$ & $1 \mathrm{k}$ & $0 \mathrm{i}$ & 98 & 100 & $\ldots$ & $\ldots$ & $\ldots$ & $\ldots$ & $\ldots$ & $\ldots$ \\
\hline Cyprodinil + fludioxionil & $48 \mathrm{~b}$ & $28 \mathrm{c}$ & $0 \mathrm{k}$ & $0 \mathrm{i}$ & 100 & 100 & $\ldots$ & $\ldots$ & $\ldots$ & $\ldots$ & $\ldots$ & $\ldots$ \\
\hline Tetraconazole & $57 \mathrm{~b}$ & $6 \mathrm{e}$ & $10 \mathrm{j}$ & $0 \mathrm{i}$ & 82 & 100 & $\ldots$ & $\ldots$ & $\ldots$ & $\ldots$ & $\ldots$ & $\ldots$ \\
\hline Myclobutanil & $84 \mathrm{a}$ & $5 \mathrm{e}$ & $16 \mathrm{i}$ & $0 \mathrm{i}$ & 71 & 100 & $\ldots$ & $\ldots$ & $\ldots$ & $\ldots$ & $\ldots$ & $\ldots$ \\
\hline Dimethomorph & $92 \mathrm{a}$ & $70 \mathrm{~b}$ & $21 \mathrm{~h}$ & $30 \mathrm{~g}$ & 63 & 46 & $\ldots$ & $\ldots$ & $\ldots$ & $\ldots$ & $\ldots$ & $\ldots$ \\
\hline Carbendazim & $96 \mathrm{a}$ & $94 \mathrm{a}$ & $0 \mathrm{k}$ & $0 \mathrm{i}$ & 100 & 100 & $\ldots$ & $\ldots$ & $\ldots$ & $\ldots$ & $\ldots$ & $\ldots$ \\
\hline Spiroxamine & $98 \mathrm{a}$ & $81 \mathrm{ab}$ & $53 \mathrm{de}$ & $16 \mathrm{~h}$ & 6 & 71 & $\ldots$ & $\ldots$ & $\ldots$ & $\ldots$ & $\ldots$ & $\ldots$ \\
\hline Quinoxyfen & $99 \mathrm{a}$ & $100 \mathrm{a}$ & 51 ef & $50 \mathrm{f}$ & 8 & 12 & $\ldots$ & $\ldots$ & $\ldots$ & $\ldots$ & $\ldots$ & $\ldots$ \\
\hline Copper ammonium acetate & 99 a & 99 a & $57 \mathrm{bc}$ & $60 \mathrm{bc}$ & 0 & 0 & $\ldots$ & $\ldots$ & $\ldots$ & $\ldots$ & $\ldots$ & $\ldots$ \\
\hline Potassium bicarbonate & $99 \mathrm{a}$ & $100 \mathrm{a}$ & $59 \mathrm{bc}$ & $59 \mathrm{~cd}$ & 0 & 0 & $\ldots$ & $\ldots$ & $\ldots$ & $\ldots$ & $\ldots$ & $\ldots$ \\
\hline Phosphonic acid & $99 \mathrm{a}$ & $99 \mathrm{a}$ & $56 \mathrm{~cd}$ & $58 \mathrm{~d}$ & 0 & 0 & $\ldots$ & $\ldots$ & $\ldots$ & $\ldots$ & $\ldots$ & $\ldots$ \\
\hline Hydrogen peroxide & $100 \mathrm{a}$ & $100 \mathrm{a}$ & $61 \mathrm{~b}$ & $61 \mathrm{~b}$ & 0 & 0 & $\ldots$ & $\ldots$ & $\ldots$ & $\ldots$ & $\ldots$ & $\ldots$ \\
\hline Garlic & $\ldots$ & $\ldots$ & $\ldots$ & $\ldots$ & $\ldots$ & $\ldots$ & $1 \mathrm{e}$ & $2 \mathrm{f}$ & $37 \mathrm{~g}$ & $0 \mathrm{i}$ & 34 & 100 \\
\hline Lactoferrin & $\ldots$ & $\ldots$ & $\ldots$ & $\ldots$ & $\ldots$ & $\ldots$ & $28 \mathrm{c}$ & $0 \mathrm{f}$ & $17 \mathrm{i}$ & $0 \mathrm{i}$ & 70 & 100 \\
\hline Tea tree oil & $\ldots$ & $\ldots$ & $\ldots$ & $\ldots$ & $\ldots$ & $\ldots$ & $98 \mathrm{a}$ & $14 \mathrm{~d}$ & $48 \mathrm{f}$ & $0 \mathrm{i}$ & 15 & 100 \\
\hline Honey & $\ldots$ & $\ldots$ & $\ldots$ & $\ldots$ & $\ldots$ & $\ldots$ & $99 a$ & $100 \mathrm{a}$ & $66 \mathrm{a}$ & $70 \mathrm{a}$ & 0 & 0 \\
\hline Sard Laundry & $\ldots$ & $\ldots$ & $\ldots$ & $\ldots$ & $\ldots$ & $\ldots$ & $100 \mathrm{a}$ & $100 \mathrm{a}$ & $59 \mathrm{bc}$ & $59 \mathrm{~d}$ & 0 & 0 \\
\hline
\end{tabular}

y Efficacy was based on the mean percent germination of 300 ascospores and mean colony diameter after 7 days on fungicide-amended potato dextrose agar (PDA) with 12 replications. Values within a column with the same letter are not significantly different $(P \leq 0.05)$. Mean separation of germination percentage is based on In transformation but values shown are back-transformed to original scale.

z Percentage inhibition of colony growth was calculated for treatments based on colony diameter and by comparison with controls on unamended PDA. 
The effect of treatments on mycelial growth was assessed by placing mycelium plugs ( $5 \mathrm{~mm}$ in diameter) of $E$. lata isolate DAR 79088 (Australian Scientific Collections Unit) taken from the margin of cultures in the center of amended and control PDA plates. The experiment was arranged as a randomized block design with 12 replications and cultures were incubated under 12-h cycles of fluorescent light and darkness at $23^{\circ} \mathrm{C}$ for 7 days. Culture diameter was measured along two perpendicular lines and diameters averaged.

Field evaluation, manual application. Three field trials were established in the winter of successive years to evaluate the efficacy of 11 fungicides and two alternative treatments (Table 1) as pruning wound protectants. Treatments were selected based on results of in vitro experiments in this study, previous research, and advice from industry. Trials were conducted at the Nuriootpa Research Centre, Barossa Valley, South Australia using Vitis vinifera 'Cabernet Sauvignon' vines planted in 1984.

In field trial 1, 1-year-old canes were pruned to two buds using pruning shears on 20 July 2005. Within $2 \mathrm{~h}$ of pruning, treatments (Table 3) were applied until runoff to 10 pruning wounds on each vine using a paint brush. Controls, inoculated (I) and not inoculated (NI), were treated with SDW. The following day, wounds were moistened by spraying with SDW immediately prior to inoculation with approximately 1,000 ascospores of $E$. lata suspended in $20 \mu \mathrm{l}$ of SDW and applied using a pipette; the inoculum spread automatically over the moist surface. NI control vines were exposed to natural infection. The trial was set up as a randomized block design with seven replicate vines per treatment using 56 grapevines.

In field trial 2, 1-year-old canes were pruned to two buds on 18 July 2006. Selected treatments (Table 4) were applied to fresh pruning wounds using a paint brush, as described above. Two hours after treatments were applied, all pruning wounds, except those on NI controls, were inoculated with 500 ascospores of $E$. $l a t a$, as described for field trial 1 . The trial was set up as a randomized block design with 11 replicate vines per treatment using 132 vines.

In field trial 3, 1-year-old canes were pruned to two buds on 8 July 2008. Within $2 \mathrm{~h}$, selected treatments (Table 5) were applied until runoff to 10 pruning wounds on each vine, using a paint brush or spray bottle depending on the material applied. Pentrabark (Agrichem) surfactant was added to myclobutanil fungicide; therefore, both products were applied alone for comparison. All pruning wounds, except those on NI controls, were inoculated twice, $2 \mathrm{~h}$ and 4 days after treatment, each with 500 ascospores of $E$. lata, as described above. The purpose of the double inoculation was to ensure sufficient infection in controls for statistical analysis. The trial was set up as a randomized block design with 11 replicate vines per treatment using 132 vines.

Table 3. Field trial 1, 2005-06: efficacy of treatments when applied immediately after pruning, and inoculation on the following day with 1,000 Eutypa lata spores per wound

\begin{tabular}{|c|c|c|c|}
\hline Treatment $^{\mathrm{x}}$ & $\begin{array}{c}\text { Application } \\
\text { rate (a.i./liter) }\end{array}$ & MPR $^{\mathbf{y}}$ & MPDC $^{\mathbf{z}}$ \\
\hline NI control & $\ldots$ & $12 \mathrm{de}$ & $\ldots$ \\
\hline I control & $\ldots$ & $79 \mathrm{a}$ & $\ldots$ \\
\hline Tebuconazole (Gelseal) & $10 \mathrm{~g}$ & $0 \mathrm{e}$ & 100 \\
\hline Tebuconazole (Greenseal) & $10 \mathrm{~g}$ & 5 de & 94 \\
\hline Carbendazim & $5 \mathrm{~g}$ & $16 \mathrm{~d}$ & 80 \\
\hline Carbendazim & $1 \mathrm{~g}$ & $32 \mathrm{c}$ & 60 \\
\hline Cyprodinil + fludioxionil & $3+2 g$ & $36 \mathrm{c}$ & 55 \\
\hline Pyraclostrobin & $0.4 \mathrm{~g}$ & $64 \mathrm{~b}$ & 18 \\
\hline
\end{tabular}

${ }^{\mathrm{x}} \mathrm{NI}=$ not inoculated and $\mathrm{I}=$ inoculated.

${ }^{y}$ Efficacy was based on the mean percent recovery (MPR) of E. lata from the treated canes by isolation on potato dextrose agar. Values within a column with the same letter are not significantly different from one another $(P \leq 0.05)$.

${ }^{\mathrm{z}}$ Mean percent disease control (MPDC) of treatments was calculated as $\mathrm{MPDC}=100 \times\left[1-\left(\mathrm{MPR}_{\text {treatment }} / \mathrm{MPR}_{\mathrm{I} \text { control }}\right)\right]$.
Field evaluation, spray application. Three spray trials were established between 2005 and 2009 to evaluate the efficacy of applying fungicide to pruning wounds with commercial spray equipment.

Spray trial 1 was established at the Nuriootpa Research Centre using V. vinifera 'Cabernet Sauvignon' vines planted in 1984. On 19 July 2005, 1-year-old canes were pruned to two buds using pruning shears. Carbendazim (2.5 g a.i./liter) was applied with a ducted, air-assisted sprayer (Hardi Mini SPV; Hardi Australia) with output rate of 366 liters/ha, a prototype multi-fan sprayer with output rate of 600 liters/ha, or with a paintbrush, along with I and NI controls. Each treatment was applied to 14 replicate vines as follows. Ten spurs on each vine were pruned and covered with plastic bags and secured with rubber bands; bags were removed and replaced so that only wounds on vines allocated to a particular treatment were exposed as appropriate when the sprayer passed. On the following day, all pruning wounds, apart from NI controls, were inoculated with 1,000 ascospores of E. lata, as described above. The trial was set up as a randomized block design using 70 vines in total.

Table 4. Field trial 2, 2006-07: efficacy of treatments when applied at different rates immediately after pruning, and inoculation $2 \mathrm{~h}$ after treatment with 500 Eutypa lata spores per wound

\begin{tabular}{lccc}
\hline Treatment $^{\mathbf{x}}$ & $\begin{array}{c}\text { Application } \\
\text { rate (a.i./liter) }\end{array}$ & MPR $^{\mathbf{y}}$ & MPDC $^{\mathbf{z}}$ \\
\hline NI control & $\ldots$ & $3 \mathrm{e}$ & $\ldots$ \\
I control & $\ldots$ & $26 \mathrm{ab}$ & $\ldots$ \\
Pyrimethanil & $8 \mathrm{~g}$ & $7 \mathrm{e}$ & 75 \\
Carbendazim & $1 \mathrm{~g}$ & $8 \mathrm{e}$ & 69 \\
Fluazinam & $5 \mathrm{~g}$ & $9 \mathrm{de}$ & 65 \\
Carbendazim & $0.5 \mathrm{~g}$ & $10 \mathrm{cde}$ & 62 \\
Pyraclostrobin & $0.2 \mathrm{~g}$ & $16 \mathrm{bcde}$ & 41 \\
Myclobutanil & $0.5 \mathrm{~g}$ & $22 \mathrm{abcd}$ & 16 \\
Myclobutanil & $0.1 \mathrm{~g}$ & $23 \mathrm{abc}$ & 14 \\
Pyrimethanil & $1.6 \mathrm{~g}$ & $24 \mathrm{ab}$ & 9 \\
Fluazinam & $1 \mathrm{~g}$ & $26 \mathrm{ab}$ & 2 \\
Pyraclostrobin & $1 \mathrm{~g}$ & $29 \mathrm{a}$ & 0 \\
\hline
\end{tabular}

${ }^{x} \mathrm{NI}=$ not inoculated and $\mathrm{I}=$ inoculated.

${ }^{y}$ Efficacy was based on the mean percent recovery (MPR) of E. lata from the treated canes by isolation on potato dextrose agar. Values within a column with the same letter are not significantly different from one another $(P \leq 0.05)$.

${ }^{\mathrm{z}}$ Mean percent disease control (MPDC) of treatments was calculated as $\mathrm{MPDC}=100 \times\left[1-\left(\mathrm{MPR}_{\text {treatment }} / \mathrm{MPR}_{\mathrm{I} \text { control }}\right)\right]$.

Table 5. Field trial 3, 2008-09: efficacy of treatments when applied at different rates immediately after pruning, and inoculation twice with 500 Eutypa lata spores per wound, $2 \mathrm{~h}$ and 4 days after treatment

\begin{tabular}{lccc}
\hline Treatment & $\begin{array}{c}\text { Application rate } \\
\text { (a.i./liter) }\end{array}$ & MPR $^{\mathbf{w}}$ & MPDC $^{\mathbf{x}}$ \\
\hline NI control & $\ldots$ & $3 \mathrm{e}$ & $\ldots$ \\
I control & $\ldots$ & $62 \mathrm{a}$ & $\ldots$ \\
Tebuconazole $^{\mathrm{y}}$ & $1.29 \mathrm{~g}$ & $15 \mathrm{e}$ & 76 \\
Carbendazim $^{\mathrm{y}}$ & $1 \mathrm{~g}$ & $17 \mathrm{e}$ & 73 \\
Myclobutanil + Pentrabark $^{\mathrm{z}}$ & $0.03 \mathrm{~g}+25 \mathrm{ml}$ & $42 \mathrm{~d}$ & 32 \\
Garlic $^{\mathrm{y}}$ & $10 \mathrm{ml}$ & $46 \mathrm{~cd}$ & 25 \\
Cyprodinil + fludioxionil $^{\mathrm{y}}$ & $0.3+0.2 \mathrm{~g}$ & $47 \mathrm{bcd}$ & 24 \\
Lactoferrin $^{\mathrm{y}}$ & $10 \mathrm{~g}$ & $48 \mathrm{abcd}$ & 21 \\
Myclobutanil $^{\mathrm{z}}$ & $0.03 \mathrm{~g}$ & $55 \mathrm{abcd}$ & 11 \\
Tetraconazole $^{\mathrm{y}}$ & $0.012 \mathrm{~g}$ & $58 \mathrm{abc}$ & 6 \\
Fenarimoly $^{\mathrm{y}}$ & $0.024 \mathrm{~g}$ & $61 \mathrm{ab}$ & 1 \\
Pentrabark $^{\mathrm{z}}$ & $25 \mathrm{ml}$ & $62 \mathrm{a}$ & 0 \\
\hline
\end{tabular}

$\mathrm{v} \mathrm{NI}=$ not inoculated and $\mathrm{I}=$ inoculated.

${ }^{\text {w }}$ Efficacy was based on the mean percent recovery (MPR) of E. lata from the treated canes by isolation on potato dextrose agar. Values within a column with the same letter are not significantly different from one another $(P \leq 0.05)$.

${ }^{x}$ Mean percent disease control (MPDC) of treatments was calculated as $\mathrm{MPDC}=100 \times\left[1-\left(\mathrm{MPR}_{\text {treatment }} / \mathrm{MPR}_{\mathrm{I} \text { control }}\right)\right]$.

y Applied with a paint brush.

z Applied with a spray bottle. 
Spray trials 2 and 3 were established in a Coonawarra vineyard near Penola, South Australia using $V$. vinifera 'Riesling' vines planted in 1981. One-year-old canes were pruned to two buds on 17 July 2007 and 23 July 2008 for spray trials 2 and 3, respectively. Carbendazim (1 g a.i./liter) was applied with an air-shear sprayer (Silvan Turbo Wrap; Silvan) at 230 or 200 liters/ha in spray trials 2 and 3, respectively; a multi-fan sprayer (Croplands Quantum mist; Croplands) at 200 liters/ha; or a paintbrush, along with I and NI controls. Each treatment was applied to 10 pruned spurs on 10 replicate vines as described for spray trial 1 . For spray trial 2 , all pruning wounds, apart from NI controls, were inoculated the following day with 500 ascospores of E. lata, as described above. For spray trial 3, all wounds, apart from NI controls, were inoculated twice with 500 ascospores, $4 \mathrm{~h}$ after treatment and on the following day, to ensure sufficient infection for statistical analysis. Spray trials 2 and 3 were set up as a randomized block design using 50 vines in total.

Assessment of infection. For each field and spray trial, spurs were excised 12 months after treatment and taken to the laboratory for morphological analysis. Bark was removed from each cane using a sharp knife and the exposed wood was surface-sterilized in $2.5 \%$ sodium hypochlorite containing a drop of Tween 20 (SigmaAldrich) per $500 \mathrm{ml}$ of solution for $12 \mathrm{~min}$ and rinsed twice in SDW. Sterilized pruning shears were then used to excise wood chips (approximately 3 by 2 by $2 \mathrm{~mm}$ ) from each side of the margin between discolored and apparently healthy wood. For each treated spur, five wood chips were plated onto each of two plates of PDA amended with streptomycin sulfate $(0.0025 \%$; SigmaAldrich), giving a total of 10 wood chips per treated spur. Cultures were incubated under 12-h cycles of fluorescent light and darkness at $23^{\circ} \mathrm{C}$ for 7 days, then assessed for the presence or absence of $E$. lata based on morphology of mycelium (10). Results were calculated as mean percentage recovery (MPR) of $E$. lata from spurs per treatment, and mean percent disease control (MPDC) was calculated as the reduction in MPR as a proportion of the inoculated control $\left(\mathrm{MPDC}=100 \times\left[1-\left(\mathrm{MPR}_{\text {treatment }} / \mathrm{MPR}_{\mathrm{I} \text { control }}\right)\right]\right)$.

Statistical analysis. Data from in vitro experiments and field trials were subjected to analysis of variance (v 8; Statistix for Windows) and least significant difference used for all pairwise comparisons at the $5 \%$ level.

\section{Results}

In vitro evaluation. On nonamended agar, $99 \%$ of the ascospores germinated, whereas germination on tebuconazole and fenarimol at $1 \mathrm{ppm}, 7$ and 28\%, respectively, was significantly $(P \leq$ $0.05)$ less (Table 2$)$. At $10 \mathrm{ppm}$, these fungicides significantly $(P \leq$ $0.05)$ reduced germination to 6 and 7\%, respectively. Myclobutanil and tetraconazole at $10 \mathrm{ppm}$ significantly $(P \leq 0.05)$ reduced germination to 5 and $6 \%$, respectively. Cyprodinil + fludioxionil sig-

Table 6. Spray trial 1, 2005-06: efficacy of carbendazim (2.5 g a.i./liter) when applied by air-assisted (Hardi) and fan (Croplands) sprayers compared with application by paint brush in Barossa Valley, South Australia

\begin{tabular}{|c|c|c|}
\hline Treatment $^{\mathrm{v}}$ & MPR $^{\mathbf{w}}$ & MPDC $^{x}$ \\
\hline NI control & $3 \mathrm{c}$ & .. \\
\hline I control & $60 \mathrm{a}$ & \\
\hline Paint brush & $3 c$ & 96 \\
\hline Fan sprayery & $5 \mathrm{c}$ & 92 \\
\hline Air-assisted sprayer ${ }^{2}$ & $26 \mathrm{~b}$ & 57 \\
\hline \multicolumn{3}{|c|}{$\begin{array}{l}{ }^{\mathrm{v}} \mathrm{NI}=\text { not inoculated and } \mathrm{I}=\text { inoculated. } \\
{ }^{\mathrm{w}} \text { Efficacy was based on the mean percent recovery }(\mathrm{MPR}) \text { of } E \text {. lata from } \\
\text { the treated canes by isolation on potato dextrose agar. Wounds were } \\
\text { treated immediately after pruning and inoculated on the following day } \\
\text { with } 1,000 \text { Eutypa lata spores per wound. Values within a column with } \\
\text { the same letter are not significantly different from one another }(P \leq 0.05) \text {. } \\
{ }^{\mathrm{x}} \text { Mean percent disease control of treatments was calculated as MPDC } \\
100 \times\left[1-\left(\mathrm{MPR}_{\text {treatment }} / \mathrm{MPR}_{\mathrm{I} \text { control }}\right)\right] \text {. } \\
1000 \text {. } \\
\text { y Application rate } 600 \text { liters } / \mathrm{ha} \text {. } \\
{ }^{\mathrm{z}} \text { Application rate } 366 \text { liters } / \mathrm{ha} \text {. }\end{array}$} \\
\hline
\end{tabular}

nificantly $(P \leq 0.05)$ reduced ascospore germination to less than $50 \%$ but most other fungicides had relatively little effect at 1 or $10 \mathrm{ppm}$.

In the second experiment, mean diameter of E. lata colonies after 7 days was $56 \mathrm{~mm}$ on nonamended PDA. Mycelial growth was completely inhibited by carbendazim and cyprodinil + fludioxionil at both 1 and $10 \mathrm{ppm}$. Myclobutanil, tebuconazole, tetraconazole, and fenarimol significantly $(P \leq 0.05)$ inhibited mycelial growth by between 71 and $98 \%$ at $1 \mathrm{ppm}$ and prevented growth at $10 \mathrm{ppm}$.

Of the alternative treatments, only garlic extract and lactoferrin at $1 \%$ reduced ascospore germination significantly $(P \leq 0.05)$, to 1 and $28 \%$, respectively. Mycelial growth was significantly $(P \leq$ 0.05 ) reduced by $1 \%$ lactoferrin, garlic, and tea tree oil by 70,34 , and $17 \%$, respectively. At $10 \%$, lactoferrin prevented germination; garlic extract and tea tree oil reduced germination to 2 and $14 \%$, respectively; and colony growth was inhibited completely by all three treatments. Sard laundry powder had no effect and honey increased spore germination and mycelial growth of E. lata.

Field evaluation, manual application. In field trial $1, E$. lata was recovered from $79 \%$ of I controls (inoculated with 1,000 spores per wound) and $12 \%$ from NI controls (Table 3 ). Compared with I controls, all treatments significantly $(P \leq 0.05)$ reduced the MPR of E. lata, which ranged from 0 to $64 \%$. E. lata was recovered from none of the canes treated with Gelseal (gel with tebuconazole at $10 \mathrm{~g}$ a.i/liter) and from $5 \%$ of canes treated with Greenseal (paint with tebuconazole at $10 \mathrm{~g}$ a.i./liter). Both were significantly $(P \leq 0.05)$ more effective than carbendazim, where $E$. lata was recovered from 32 and $16 \%$ of wounds treated with 1 and $5 \mathrm{~g}$ a.i./liter, respectively.

In field trial 2, E. lata was recovered from $26 \%$ of I controls (500 spores/wound) and from $3 \%$ of NI controls (Table 4). Pyrimethanil ( $8 \mathrm{~g}$ a.i./liter), carbendazim ( 0.5 and $1 \mathrm{~g}$ a.i./liter), and fluazinam $(5 \mathrm{~g}$ a.i./liter) significantly $(P \leq 0.05)$ reduced the MPR of $E$. lata to 7 to $10 \%$. All other treatments did not reduce infection significantly.

In field trial 3, E. lata was recovered from $62 \%$ of I controls (1,000 spores/wound) and from $3 \%$ of NI controls (Table 5). Tebuconazole (1.29 $\mathrm{g}$ a.i./liter) and carbendazim ( $1 \mathrm{~g}$ a.i./liter $)$ reduced the MPR of $E$. lata to 15 and $17 \%$, respectively, significantly $(P \leq$ $0.05)$ less than that of all other treatments evaluated. Myclobutanil (0.032 $\mathrm{g}$ a.i./liter) reduced the MPR of E. lata to $55 \%$ whereas, when combined with the surfactant Pentrabark at $25 \mathrm{ml} / \mathrm{liter}$, the MPR $(42 \%)$ was significantly $(P \leq 0.05)$ less than that of the I control. Garlic extract (10 ml/liter) and lactoferrin (10 g/liter) significantly $(P \leq 0.05)$ decreased the MPR to 46 and $48 \%$, respectively, providing 25 and $21 \%$ control, respectively.

Field evaluation, spray application. In spray trial 1, E. lata was recovered from $60 \%$ of I controls (1,000 spores/wound) and from $3 \%$ of naturally infected controls (Table 6). Carbendazim (2.5 $\mathrm{g}$ a.i./liter) significantly $(P \leq 0.05)$ reduced the MPR of $E$. lata to between 3 and $26 \%$ when applied by paintbrush or either sprayer. Application with the fan sprayer provided $92 \%$ control, similar to that achieved by using a paintbrush $(96 \%)$.

In spray trial 2, E. lata was recovered from $19 \%$ of I controls $(1,000$ spores/wound) and from $1 \%$ of naturally infected controls (Table 7). Carbendazim (1 g a.i./liter) significantly $(P \leq 0.05)$ reduced MPR of E. lata to between 4 and $13 \%$ when applied by paintbrush or either sprayer. The fan and air-shear sprayers provided less control (30 and 49\%, respectively) than did application using a paintbrush (78\%).

In spray trial 3, E. lata was recovered from $60 \%$ of I controls (1,000 spores/wounds) and was not isolated from naturally infected controls (Table 7). Carbendazim (1 g a.i./liter) significantly $(P \leq$ 0.05 ) reduced MPR of $E$. lata to between 4 and $34 \%$ when applied by paintbrush or either sprayer. The fan and air-shear sprayers provided less control (53 and 43\%, respectively) than did application using a paintbrush (93\%).

\section{Discussion}

In vitro assessment of various fungicides registered in Australia for use on grapevines to control other pathogens showed that sev- 
eral had the potential to control E. lata. These products, which represent a range of fungicide activity groups, inhibited ascospore germination or mycelial growth. In addition, some alternative natural treatments showed potential for control of E. lata. Treatments effective in vitro were further evaluated in the field trials, along with a paint and gel which could not easily be tested for fungicidal activity in vitro and other treatments that were not available at the time of in vitro testing.

Carbendazim was included in this study although it is no longer permitted for use on grapevines in Australia. It was included for comparative purposes, having proved effective at reducing infection of grapevine pruning wounds by E. lata in France, when mixed with flusilazole (21), and when used alone in Greece (7) and Australia (37). It was also used for evaluating methods of spray application. In vitro testing confirmed that carbendazim inhibits mycelial growth rather than germination, which was also the case for another benzimidazole fungicide, benomyl (37). In this study, carbendazim provided 60 to $96 \%$ disease control on vines in the field when applied at 1 to $5 \mathrm{~g}$ a.i./liter with a paint brush to pruning wounds prior to inoculation with ascospores of $E$. lata.

The demethylation inhibitor fungicide tebuconazole provided a level of control similar to that of carbendazim. Tebuconazole, when applied with a paint brush to pruning wounds as Folicur (at $1.3 \mathrm{~g}$ a.i./liter) and in the formulation of Greenseal ( $10 \mathrm{~g}$ a.i./liter) and Gelseal (10 g a.i./liter), provided 76, 94, and $100 \%$ disease control, respectively. Although tebuconazole reduced mycelial growth of $E$. lata in previous in vitro studies $(17,18)$, this is the first known report of its efficacy for control of E. lata in the vineyard. Gramaje et al. (17) recently reported reduction of mycelial growth of other species of the Diatrypaceae in vitro by tebuconazole. The efficacy of tebuconazole against species of the Botryosphaeriaceae has also been reported $(1,31)$. Therefore, tebuconazole shows promise as a pruning wound protectant for the control of trunk diseases caused by species of the Diatrypaceae and Botryosphaeriaceae and, hence, is the focus of continuing research.

The anilinopyrimidine fungicide pyrimethanil, applied with a paint brush to pruning wounds as Scala (at $8 \mathrm{~g}$ a.i./liter), provided $75 \%$ control of E. lata but only $9 \%$ control when applied at $1.6 \mathrm{~g}$ a.i./liter. In previous research, pyrimethanil provided 55 to $71 \%$ disease control when applied at $6 \mathrm{~g}$ a.i./liter (37). Pyrimethanil may have potential as a pruning wound protectant against $E$. lata; however, in vitro studies showed that it was ineffective at reducing mycelial growth of species of the Diatrypaceae (17) and Botryosphaeriaceae $(1,6)$.

The 2,6-dinitro-analine fungicide fluazinam, applied with a paint brush to pruning wounds as Shirlan (5 g a.i./liter), provided $65 \%$ control of E. lata, supporting previous research in which application of 1 to $12.5 \mathrm{~g}$ a.i./liter provided 38 to $86 \%$ control (37). Likewise, fluazinam controlled infection of pruning wounds by $E$. lata in Greece (7) and reduced mycelial growth of species of the Diatrypaceae in vitro (17). Efficacy against species of the Botryosphaeriaceae has also been reported (31).

Cyprodinil + fludioxionil (Switch) and pyraclostrobin (Cabrio), when applied by paint brush, controlled infection of pruning wounds by E. lata to a lesser extent ( 0 to $55 \%$ ) than the abovementioned fungicides. There is limited information on the efficacy of these fungicides for E. lata and species of Botryosphaeriaceae $(31,35,37)$. However, based on these results, there is merit in further evaluation at higher application rates because it may lead to the identification of fungicides from different activity groups for the management of trunk diseases. Other fungicides applied to wounds by paint brush in this study did not reduce infection of pruning wounds by E. lata despite their ability to reduce mycelial growth in vitro.

Pentrabark is a silicone-based surfactant specifically designed for surface treatment of trees to assist translocation of pesticides through the lenticels in bark into the vascular system (5). In field trial 3, the addition of Pentrabark to myclobutanil (Mycloss) resulted in a threefold improvement in control of E. lata, from 11 to $32 \%$, which supports recommendations for application of myclo- butanil (Rally) and thiophanate methyl (Topsin M) with surfactant in California (W. Gubler, personal communication).

In this study, the wound protectant paint (Greenseal) and gel (Gelseal) provided 94 and $100 \%$ control of E. lata, respectively. Both of these formulations include tebuconazole but the relative contributions of the paint or gel as a barrier to ascospores entering xylem vessels in the wound and the fungicide are unclear. Rolshausen and Gubler (34) reported significantly greater control with a boric acid and paste mix (biopaste) than with the paste alone, whereas Sosnowski et al. (37) reported no difference in efficacy between application of acrylic paint with or without benomyl, carbendazim, and boric acid. Efficacy is likely to be influenced by factors such as timing of application, wound size, and climatic conditions, and further research is required to evaluate efficacy and mechanisms. Paint and paste products have proved to be effective pruning wound protectants against $E$. lata and species of the Botryosphaeriaceae $(31,34,35,37)$. However these treatments need to be applied by hand, making it difficult to achieve cost-effective control for routine use in vineyards.

Of the four natural treatments evaluated to control $E$. lata in vitro, garlic and lactoferrin were assessed in the field and, when applied to pruning wounds at $1 \%$ concentration, provided 25 and $21 \%$ control of E. lata, respectively. Although less than achieved with tebuconazole and carbendazim, control was better than that achieved with a number of conventional fungicides. The natural products may be more effective applied at higher concentrations. Garlic extract (2) and lactoferrin (20) are known to have antimicrobial properties and, if effective, may be useful alternatives for use in organic viticulture or to reduce pesticide use in conventionally managed vineyards.

Neither processed honey nor hydrogen peroxide (Proxitane) reduced germination or mycelial growth of E. lata. In comparison, Chen et al. (15) found unprocessed honey to control the human pathogen Candida albicans and attributed this effect to the absence of heat treatment compared with processed honey. Although it is possible that the addition of the processed honey to molten agar at $60^{\circ} \mathrm{C}$ may have further impaired antifungal activity, further investigation was not warranted because storage in the hot southern Australian summer would be problematic.

The application of fungicide to pruning wounds with tractordriven spray machinery provided new information for several types of spray equipment not previously evaluated. Air-blast (33) and recycle (21) sprayers were used to achieve effective control of $E$. lata using benomyl and a flusilazole-carbendazim mix, respectively. Herche and Gubler (19) reported control of E. lata with myclobutanil sprays but details of the spray equipment were not provided. Here, we showed that carbendazim applied with air-

Table 7. Spray trials 2 and 3, 2007-08 and 2008-09, respectively: efficacy of carbendazim ( $1 \mathrm{~g}$ a.i./liter) when applied by air-shear (Silvan) and fan (Croplands) sprayers compared with application by paint brush, in a field trial in Coonawarra, South Australia

\begin{tabular}{lcccccc}
\hline & \multicolumn{2}{c}{ Spray trial 2 } & & \multicolumn{2}{c}{ Spray trial 3 } \\
\cline { 2 - 3 } \cline { 5 - 6 } Treatment $^{\mathbf{v}}$ & MPR $^{\mathbf{w}}$ & MPDC $^{\mathbf{x}}$ & & MPR $^{\mathbf{w}}$ & MPDC $^{\mathbf{x}}$ \\
\hline NI control & $1 \mathrm{c}$ & $\ldots$ & & $0 \mathrm{c}$ & $\ldots$ \\
I control & $19 \mathrm{a}$ & $\ldots$ & & $60 \mathrm{a}$ & $\ldots$ \\
Paint brush & $4 \mathrm{c}$ & 78 & & $4 \mathrm{c}$ & 93 \\
Air-shear sprayer $^{\mathrm{y}}$ & $10 \mathrm{c}$ & 49 & & $34 \mathrm{~b}$ & 43 \\
Fan sprayer $^{\mathrm{z}}$ & $13 \mathrm{~b}$ & 30 & & $28 \mathrm{~b}$ & 53 \\
\hline
\end{tabular}

${ }^{\mathrm{v}} \mathrm{NI}=$ not inoculated and $\mathrm{I}=$ inoculated.

${ }^{\text {w}}$ Efficacy was based on the mean percent recovery (MPR) of E. lata from the treated canes by isolation on potato dextrose agar. Wounds were treated immediately after pruning, and inoculated once with 500 Eutypa lata spores per wound on the following day (spray trial 2) or twice $2 \mathrm{~h}$ and 4 days after treatment (spray trial 3 ). Values within a column with the same letter are not significantly different from one another $(P \leq 0.05)$.

${ }^{\mathrm{x}}$ Mean percent disease control of treatments was calculated as MPDC $=$ $100 \times\left[1-\left(\mathrm{MPR}_{\text {treatment }} / \mathrm{MPR}_{\mathrm{I} \text { control }}\right)\right]$.

${ }^{y}$ Application rate 230 liters/ha for trial 2 and 200 liter/ha for trial 3.

${ }^{\mathrm{z}}$ Application rate 200 liters/ha for trials 2 and 3 . 
assisted, air-shear, and fan sprayers provided control of $E$. lata, and efficacy increased with volume rates. Moreover, at 600 liters/ha, the fan sprayer provided control similar to that obtained with paint brush application.

To ensure significant establishment of infection in controls in these studies, wounds were inoculated with 500 or 1,000 ascospores, which is 50 to 100 times the number estimated to infect apricot pruning wounds naturally (11). Up to $12 \%$ of wounds were infected naturally, which was much less than the incidence of infection in the inoculated controls (26 to $79 \%$ ) across the trials. Larger wounds would be expected to have higher rates of infection based on the greater surface area (10). Hence, some treatments which afforded poor control and were less effective than carbendazim may be more effective when wounds are infected naturally.

Recommendations for the control of E. lata in vineyards since the early 1980s have been based on wound protection (26). Following the loss of benomyl and carbendazim, this study suggests that a number of alternative effective pruning wound treatments can reduce infection by $E$. lata. Cost-effective spray application of fungicides to pruning wounds now seems feasible and further evaluation of this technique will provide greater control of Eutypa dieback in the future.

\section{Acknowledgments}

This research was supported by Australian grapegrowers through the Grape and Wine Research and Development Corporation, with matching funds from the Federal Government. We thank T. Gerlach and T. Hebberman for maintenance of trials at the Nuriootpa Research Centre, and D. Sosnowski and A. Walter for technical assistance.

\section{Literature Cited}

1. Amponsah, N. T., Jones, E., Ridgeway, H. J., and Jaspers, M. V. 2012. Evaluation of fungicides for the management of Botryosphaeria dieback diseases of grapevines. Pest Manage. Sci. 68:676-683.

2. Ankri, S., and Mirelman, D. 1999. Antimicrobial properties of allicin from garlic. Microbes Infect. 1:125-129.

3. Anonymous 2001. Benomyl RED Facts. United States Environmental Protection Agency Factsheet EPA-738-F-02-001, November 2001. http://www. epa.gov/oppsrrd1/REDs/factsheets/benomyl fs.htm

4. Anonymous 2010. Suspension of label approvals of products containing carbendazim. Pages 41-45 in: Commonwealth of Australia Gazette, Australian Pesticides and Veterinary Medicines Authority. No. APVMA 2. http://www.apvma.gov.au/publications/gazette/2010/02/gazette_2010_02_0 2_page_41.pdf

5. Anonymous 2013. Pentra-bark. Technical Data Sheet. Quest Products Corporation, Louisburg, KS. http://www.questproducts.us/pdf/pentraBark TDS.pdf

6. Bester, W., Crous, P. W., and Fourie, P. H. 2007. Evaluation of fungicides as potential grapevine pruning wound protectants against Botryosphaeria species. Australas. Plant Pathol. 36:73-77.

7. Bourbos, V. A., and Barbopoulou, E. A. 2005. Study of the possibility to control Eutypa lata (Pers. Fr.) Tul. in grapevine. Phytopathol. Mediterr. 44:116.

8. Carter, M. V. 1957. Eutypa armeniacae Hansf. and Carter, sp. nov., an airborne vascular pathogen of Prunus armeniaca L. in southern Australia. Aust. J. Bot. 5:21-35.

9. Carter, M. V. 1960. Further studies on Eutypa armeniacae Hansf. \& Carter. Aust. J. Agric. Res. 11:498-504.

10. Carter, M. V. 1991. The status of Eutypa lata as a pathogen. Monogr. Phytopathol. Pap. No. 32. International Mycological Institute, Surrey, UK.

11. Carter, M. V., and Moller, W. J. 1971. The quantity of inoculum required to infect apricot and other Prunus species with Eutypa armeniacae. Aust. J. Exp. Agric. Anim. Husb. 11:684-686.

12. Carter, M. V., and Perrin, E. 1985. A pneumatic-powered spraying secateur for use in commercial orchards and vineyards. Aust. J. Exp. Agric. 25:939-942.

13. Carter, M. V., and Price, T. V. 1975. Biological control of Eutypa armeniacae. III. A comparison of chemical, biological and integrated control. Aust. J. Agric. Res. 26:537-543.

14. Carter, M. V., and Price, T. V. 1977. Explanation of the failure of a commercial scale application of benomyl to protect pruned apricot trees against $\mathrm{Eu}-$ typa dieback disease. Aust. J. Exp. Agric. Anim. Husb. 17:171-173.

15. Chen, C., Campbell, L. T., Blair, S. E., and Carter, D. A. 2012. The effect of standard heat and filtration processing procedures on antimicrobial activity and hydrogen peroxide levels in honey. Front. Microbiol. 3:265.

16. Gendloff, E. H., Ramsdell, D. C., and Burton, C. L. 1983. Fungicidal control of Eutypa armeniacae infecting Concord grapevine in Michigan. Plant Dis. 67:754-756.

17. Gramaje, D., Ayres, M. R., Trouillas, F. P., and Sosnowski, M. R. 2012. Efficacy of fungicides on mycelial growth of diatrypaceous fungi associated with grapevine trunk disease. Australas. Plant Pathol. 41:295-300.

18. Halleen, F., Fourie, P. H., and Lombard P. J. 2010. Protection of grapevine pruning wounds against Eutypa lata by biological and chemical methods. South Afr. J. Enol. Vitic. 31:125-132.

19. Herche, R., and Gubler, W. D. 2010. Control strategies for trunk diseases of grapevine. Phytopathol. Mediterr. 49, 125.

20. Lahoz, E., Pisacane, A., Iannaccone, M., Palumbo, D., and Capparelli, R., 2008. Fungistatic activity of iron-free bovine lactoferrin against several fungal plant pathogens and antagonists. Nat. Product Res. 22:955-961.

21. Lecomte, P., Laveau, E., Laterriere, S. G., Dewasme, C., and Clerjeau, M. 2003. Optimisation of pruning wound protection for the control of Eutypa dieback of grapevine in France. Integr. Prot. Prod. Vitic. IOBC/wprs Bull. 26:95-96.

22. Mahoney, N., Molyneux, R. J., Smith, L. R., Schoch, T. K., Rolshausen, P. E., and Gubler, W. D. 2005. Dying-arm disease in grapevines: diagnosis of infection with Eutypa lata by metabolite analysis. J. Agric. Food Chem. 53:8148-8155.

23. Moller, W. J., and Carter, M. V. 1965. Production and dispersal of ascospores in Eutypa armeniacae. Aust. J. Biol. Sci. 18:67-80.

24. Moller, W. J., and Kasimatis, A. N. 1978. Dieback of grapevines caused by Eutypa armeniacae. Plant Dis. Rep. 62:254-258.

25. Moller, W. J., and Kasimatis, A. N. 1980. Protection of grapevine pruning wounds from Eutypa dieback. Plant Dis. 64:278-280.

26. Moller, W. J., and Kasimatis, A. N. 1981. Further evidence that Eutypa armeniacae-not Phomopsis viticola-incites dead arm symptoms on grape. Plant Dis. 65:429-431.

27. Molyneux, R. J., Mahoney, N., Bayman, P., Wong, R. Y., Meyer, K., and Irelan, N. 2002. Eutypa dieback in grapevines: differential production of acetylenic phenol metabolites by strains of Eutypa lata. J. Agric. Food Chem. 50:1393-1399.

28. Munkvold, G. P., and Marois, J. J. 1993. The effects of fungicides on Eutypa lata germination, growth, and infection of grapevines. Plant Dis. 77:50-55.

29. Munkvold, G. P., and Marois, J. J. 1995. Factors associated with variation in susceptibility of grapevine pruning wounds to infection by Eutypa lata. Phytopathology 85:249-256.

30. Pearson, R. 1982. Protection of grapevine pruning wounds from infection by Eutypa armeniacae in New York State. Am. J. Enol. Vitic. 33:51-52.

31. Pitt, W. M., Sosnowski, M. R., Huang, R., Qiu, Y., Steel, C. C., and Savocchia, S. 2012. Evaluation of fungicides for the management of Botryosphaeria canker of grapevines. Plant Dis. 96:1303-1308.

32. Ramos, D. E., Moller, W. J., and English, H. 1975. Production and dispersal of ascospores of Eutypa armeniacae in California. Phytopathology 65:1364-1371.

33. Ramsdell, D. C. 1995. Winter air-blast sprayer applications of benomyl for reduction of Eutypa dieback disease incidence in a Concord grape vineyard in Michigan. Plant Dis. 79:399-402.

34. Rolshausen, P. E., and Gubler, W. D. 2005. Use of boron for the control of Eutypa dieback of grapevines. Plant Dis. 89:734-738.

35. Rolshausen, P. E., Úrbez-Torres, J. R. Rooney-Latham, S, Eskalen, A, Smith, R. J., and Gubler, W. D. 2010. Evaluation of pruning wound susceptibility and protection against fungi associated with grapevine trunk diseases. Am. J. Enol. Vitic. 61:113-119.

36. Siebert, J. B. 2001. Eutypa: The economic toll on vineyards. Wines Vines April 50-56.

37. Sosnowski, M. R., Creaser, M. L., Wicks, T. J., Lardner, R., and Scott, E. S. 2008. Protection of grapevine pruning wounds from infection by Eutypa lata. Aust. J. Grape Wine Res. 14:134-142.

38. Tey-Rulh, P., Philippe, I., Renaud, J. M., Tsoupras, G., De Angelis, P., Fallot, J., and Tabacchi, R. 1991. Eutypine, a phytotoxin produced by Eutypa lata the causal agent of dying-arm disease of grapevine. Phytochemistry 30:471-473.

39. Weber, E. A., Trouillas, F. P., and Gubler, W. D. 2007. Double pruning of grapevines: A cultural practice to reduce infections by Eutypa lata. Am. J. Enol. Vitic. 58:61-66.

40. Wicks, T., and Davies, K. 1999. The effect of Eutypa on grapevine yield. Aust. Grapegrower Winemaker 426a:15-16. 